Željko Lovrinčević

JEL Classification E60, O40, O47

Izvorni znanstveni rad

https://doi.org/10.32910/ep.70.3.2

\title{
OVISI LI DUGOROČNI GOSPODARSKI RAST HRVATSKE O DEMOGRAFIJI ILI IPAK PROIZVODNOSTI?
}

Cilj ovog rada je izrada dugoročnih projekcija gospodarskih kretanja u Republici Hrvatskoj za razdoblje do 2050. godine. Dugoročne projekcije kretanja gospodarstva korisne su radi pravovremenog uočavanja ograničenja i potencijalnih izazova u budućem razdoblju vezanih uz različita područja: demografske promjene, fiskalnu održivost, zaštitu okoliša i mnoge druge aspekte. Izrada projekcija temelji se na Cobb-Douglasovoj tipu funkcije proizvodnje koja u svojim dugoročnim projekcijama koristi Europska komisija za sve zemlje članice. Dugoročna kretanja gospodarstva proizlaze iz demografskih projekcija, te upotrebe proizvodnih faktora, rada i kapitala. No, najveća nepoznanica ostaje kretanje proizvodnosti nekog društva u dugom roku. Rezultati istraživanja ukazuju na potrebu značajnog podizanja efikasnosti investicija i ukupne proizvodnosti proizvodnih faktora, kao i povećanje stopa aktivnosti stanovništva na tržištu rada. Na taj način se, u određenoj mjeri, mogu ublažiti negativna demografska kretanja i očekivano smanjenje broja stanovnika u radnoj dobi u budućem razdoblju.

Izrada dugoročnih projekcija uvijek je povezana s visokom razinom neizvjesnosti o kretanju brojnih varijabli u budućem razdoblju što utječe na rezultate projekcije. Prezentiranim rezultatima i zaključcima u ovom radu upotpunjena su relativno oskudna istraživanja o analiziranoj problematici u Republici Hrvatskoj. Prikazani alternativni scenariji rasta razine gospo-

${ }^{*}$ Dr. sc. Ž. Lovrinčević, znanstveni savjetnik u trajnom zvanju, Ekonomski institut, Zagreb (E-mail: zlovrincevic@eizg.hr).

Rad je primljen u uredništvo 13.02.2019. godine, a prihvaćen je za objavu 18.03.2019. godine. 
darske aktivnosti, trebaju poslužiti kao podloga za izradu različitih brojnih strateških dokumenata koji definiraju srednjoročne i dugoročne politike, poput energetske, regionalne, industrijske, demografske, zdravstvene, zaštite okoliša $i$ slično.

Rezultati istraživanja ukazuju da će prosječna stopa gospodarskog rasta u razdoblju do 2050. godina u Republici Hrvatskoj iznositi od 1,1 posto (bazni scenarij) do najviše 1,9 posto, ovisno o pretpostavkama. Stopa rasta potencijalnog BDP-a višse ovisi o kretanju faktorske proizvodnosti, nego o demografskim kretanjima.

Ključne riječi: dugoročni gospodarski rast, konvergencija, projekcije, ukupna proizvodnost faktora.

\section{Uvodna razmatranja}

Cilj ovog rada je izrada dugoročnih projekcija gospodarskih kretanja za Hrvatsku za razdoblje do 2050. godine, te identificiranje ključnih ograničenja rasta. Temeljna hipoteza rada je da glavno ograničenje za dugoročni gospodarski rast Hrvatske predstavlja rast proizvodnosti, a ne demografsko ograničenje. Demografska ograničenja su važna, ali nisu presudna za dugoročni uspjeh nacionalnog gospodarstva. Dugoročne projekcije ekonomske aktivnosti temelje se na primjeni koncepta potencijalnog outputa i proizvodnog jaza, pristupima koji su najčešce primijenjeni u različitim dokumentima institucija Europske unije (EU). Procjene potencijalnog outputa te procjena proizvodnog jaza (eng. output gap), kao razlike između stvarnog i potencijalnog outputa često su predmet ekonomskih analiza. Koncept potencijalnog bruto domaćeg proizvoda (BDP) čini osnovicu u procjeni uspješnosti fiskalne politike svih zemalja EU jer čini polaznu osnovicu za procjenu tzv. ciklički prilagođenog deficita svake zemlje članice. Temelji ukupne fiskalne i monetarne politike su navedeni u Paktu o stabilnosti i rastu. O krucijalnom značenju izračuna ciklički prilagođenog deficita koji počiva na konceptu potencijalnog BDP, vidjeti Larch i Turrini (2009).

Primjena istovrsne metodologije prema kojoj su izrađene projekcije za zemlje EU pruža mogućnost usporedbe po zemljama, odnosno uočavanju procesa konvergencije ili divergencije. Dodatna prednost primjene takve jednoznačne metodologije leži i u mogućnosti usporedbe rezultata različitih istraživanja u kojima se koristi ista metodologija, ali su različite pretpostavke i scenariji budućnosti. Valja naglasiti da je primjena rezultata ekonometrijskog modeliranja na način da se ocijenjeni parametri iz prošlog razdoblja projiciraju na buduće dugoročno razdoblje često inferiorna primjeni prilagođenih tradicionalnih modela rasta. Stoga se 
projekcije u ovom radu temelje na primjeni tradicionalnog modela rasta u kombinaciji s demografskim projekcijama za Republiku Hrvatsku (RH) i ekonomskim projekcijama za zemlje EU. Uvodi se skup racionalnih očekivanja o gospodarskim kretanjima u RH, koji čini konzistentan makroekonomski okvir za projekciju kretanja ključnih varijabli od interesa.

Ostatak ovog rada strukturiran je na sljedeći način. U drugom poglavlju dan je kratak pregled relevantne literature. Treće poglavlje opisuje metodologiju istraživanja, dok se u četvrtom prikazuju empirijski rezultati istraživanja. Posljednje poglavlje je zaključak s preporukama za daljnja istraživanja.

\section{Pregled dosadašnjih istraživanja}

Tijekom vremena razvijane su različite metode i pristupi za procjenu potencijalnog outputa i proizvodnog jaza. Pregledom relevantne i recentne literature, prikazane u nastavku ovog poglavlja, utvrđeno je da je za procjenu navedenih ekonomskih pokazatelja najčešći pristup proizvodne funkcije. Najčešće se pretpostavlja proizvodna funkcija Cobb-Douglasovog tipa (Denis et al., 2002, Havik et al., 2014).

Među novim zemljama članicama EU, Ganev (2015) je na primjeru bugarskog gospodarstva prikazao makro ekonometrijski model dizajniran za procjenu proizvodnog jaza i potencijalnog rasta gospodarstva u okruženju oskudnom podacima. Predstavljeni model slijedio je okvir Cobb-Douglas modela koji je usvojen kao metodološka osnova na razini EU, a temelji se na pristupu proizvodne funkcije s faktorima rada, kapitala i tehnološkog razvoja.

$\mathrm{Za}$ mjerenje proizvodnog potencijala gospodarstva u Cobb-Douglasovoj proizvodnoj funkciji pretpostavlja se konstantni udio radne snage u outputu, što za pojedine zemlje može biti previše restriktivan uvjet. Na primjeru češkog gospodarstva, autori Hájková i Hurník (2007) testirali su jesu li takve pretpostavke pouzdane obzirom da se udio radne snage u Češkoj postupno povećavao tijekom posljednjeg desetljeća. Rezultati analize ukazuju da ne postoje značajne razlike između izračuna temeljem Cobb-Douglasove funkcije i općenitije proizvodne funkcije u kojoj se koeficijenti elastičnosti proizvoda u odnosu na kapital i u odnosu na rad mijenjaju tijekom vremena, tj. asimptotski konvergiraju prema njihovim stabilnim vrijednostima. U pokušaju procjene potencijalnog outputa i proizvodnog jaza, Adamec i Střelec (2012) su primijenili Hodrick-Prescott filter i Cobb-Douglas funkciju. Primijenjene metode na tromjesečne i godišnje podatke češkog BDP, rada i bruto fiksnog kapitala ukazuju na različite rezultate što autori opravdavaju ograničenjima korištenih metoda kao i korištenih podataka u analizi. 
U usporedbi s pristupom Hodrick-Prescott filtra, metodologija proizvodne funkcije pokazala se boljom u identifikaciji točaka preokreta poljskog gospodarstva (Epstein i Macchiarelli, 2010). Rezultati provedene analize pokazuju da je prije krize poljskog gospodarstva, proizvodnja rasla iznad svojih potencijala, a da se pad u ukupnoj faktorskoj proizvodnosti (eng. Total Factor Productivity, TFP) podudara s usporenim rastom potencijalnog outputa. Autori smatraju da nakon globalne krize Poljska neće doživjeti znatan i trajan negativni proizvodni jaz.

Măntescu i Lazăr (2014) analizirali su utjecaj krize na potencijalni output i proizvodni jaz zemalja članica EU uključenih u programe financijske pomoći i makroekonomske prilagodbe. Stope rasta potencijalnog BDP-a računate su CobbDouglasovom funkcijom i Hodrick-Prescottovom metodologijom. U zemljama koje je pogodila ekonomska i financijska kriza stope rasta potencijalnog BDP-a znatno su usporene. Za Cipar, Grčku, Portugal, Italiju i Španjolsku zabilježene su čak i negativne stope rasta. Na dugoročni rast potencijalnog BDP-a zemalja članica EU utjecat će, i to negativno, razni faktori, kao što su povećanje averzije prema riziku, spori gospodarski oporavak te proces starenja stanovništva.

Favero i Galasso (2015) na primjeru petnaest europskih zemalja utvrđuju smanjenje stope potencijalnog rasta BDP-a u nadolazećem dugoročnom razdoblju. To pripisuju promjeni demografske strukture stanovništva na način da starija društva teže prihvaćaju strukturne reforme na tržištima rada i proizvoda, a lakše keynezijanske politike državne intervencije. To smanjuje dugoročnu stopu potencijalnog rasta BDP-a.

Glede rezultata procjene potencijalnog BDP-a za gospodarstvo SAD-a, CobbDouglasovim modelom procijenjene su vrijednosti kapitala i inputa rada (Onalan i Basegmez, 2018). Granični doprinos kapitala BDP-u iznosio je 0,403 , a doprinos inputa rada 1,094. Navedeni pokazatelji upućuju na zaključak da je gospodarstvo SAD-a radno intenzivno.

Cooley i Henriksen (2018) su utvrdili da demografske promjene objašnjavaju svega jednu šestinu promjena dugoročnog gospodarskog rasta u SAD-u i Japanu u razdoblju 1990.-2007., dok većinu promjene dinamike rasta BDP-a objašnjava promjena proizvodnosti.

Gonzalez Eiras i Niepelt (2012) potvrđuju na primjeru razvijenih OECD zemalja da demografsko starenje i demografska tranzicija, ali i produžetak radnog vijeka, smanjuju dugoročnu potencijalnu stopu rasta BDP-a per capita. Međutim, utjecaj na kapitalnu opremljenost proizvodnje je pozitivan, a rast proizvodnosti dolazi primarno kroz javne investicije.

Rezultati procjene potencijalnog rasta proizvodnje za srednjoamerička gospodarstva ukazuju na opadanje istog u posljednjih nekoliko godina u većini zemalja Srednje Amerike (Garcia-Saltos, Ruxandra Teodoru i Zhang, 2016). U budućnosti se očekuje da će potencijalni rast proizvodnje u većini srednjoamerič- 
kih gospodarstava iznositi u prosjeku od 4 posto u srednjoročnom razdoblju zbog strukturnih ograničenja rasta kapitala i zaposlenosti i niskog rasta ukupne faktorske proizvodnosti. Autori zaključuju da povećanje potencijalnog rasta treba biti prioritet politike, a strukturne reforme moraju biti usmjerene na poboljšanje uvjeta poslovanja, tržišta proizvoda i rada te na jačanje kapaciteta za inovacije.

Od radova koji su se bavili navedenom temom u RH, treba spomenuti da su Bokan i Ravnik (2012) procijenili potencijalni output RH za razdoblje od prvog tromjesečja 2000. do četvrtog tromjesečja 2010. godine. U procjeni potencijalnog outputa korištene su metoda regularizirane maksimalne vjerodostojnosti i multivarijantni Kalmanov filter. Rezultati provedene procjene ukazuju da se u periodu od drugog tromjesečja 2002. godine do drugog tromjesečja 2009. godine output nalazio iznad razine potencijalnog, dok je izvan tog razdoblja bio ispod potencijalnog. Temeljem kretanja godišnjih stopa inflacije procijenjene su serije jaza outputa. Tako je u 2008. godini u vrijeme viših stopa inflacije jaz outputa postigao najveću vrijednost, da bi se u narednom razdoblju jaz outputa naglo smanjio te doveo do smanjenja stope inflacije.

Primjena različitih metodologija za procjenu potencijalnog rasta i jaza BDP-a može rezultirati različitim rezultatima analiziranih pokazatelja stoga je u izračunima potreban oprez. Jovičić (2017) u procjeni potencijalnog rasta i jaza BDP-a uspoređuje tri metode, HP-filtra, metode proizvodne funkcije i multivarijatnog filtera, za razdoblje od 1996. do 2016. godine za RH. Rezultati analize ukazuju na smanjenje potencijalnog BDP-a i porast jaza BDP-a nakon svjetske financijske krize. Doprinos ukupne faktorske proizvodnosti potencijalnom rastu BDP-a bio je minoran, a rast znatno niži u usporedbi s drugim zemljama članica EU.

Obzirom na dugotrajnu slabu iskorištenost rada, slab rast proizvodnosti i nisku ukupnu faktorsku proizvodnost usporava se potencijalni output u RH. Da bi se potencijalni rast povećao potrebno je provođenje strukturnih reformi za brži rast proizvodnosti, uključivanje na tržište rada i poslovno okruženje privlačnije za ulaganja. Europska komisija (2018) naglašava isti problem uočen i kod drugih autora glede potencijalnog rasta BDP-a RH, a to je izrazito slab rast proizvodnosti i ukupno gledajući niska razina proizvodnosti. Nisku razinu proizvodnosti, kao glavni čimbenik zaostajanja RH za usporedivim zemljama navode također Buturac, Lovrinčević i Mikulić (2011).

\section{Metodologija istraživanja}

Metodologija izrade projekcija u ovom radu temelji se na pristupu primijenjenom u izradi dugoročnih projekcija kretanja gospodarstva EU, a koji je detaljno 
opisana u European Commission (2017). Projekcije polaze od proizvodne funkcije Cobb-Douglasovog tipa s konstantnim prinosima na obujam. Rast BDP-a rezultat je očekivanih dugoročnih kretanja radne snage i proizvodnosti rada.

U Cobb-Douglasovoj funkciji proizvodnje potencijalni BDP može se izraziti kao funkcija proizvodnih faktora rada i kapitala te ukupne faktorske proizvodnosti (1):

$$
Y=L^{\beta} \cdot K^{(1-\beta)} \cdot T F P=\left(T F P^{\frac{1}{\beta}} \cdot L\right)^{\beta} \cdot K^{1-\beta}=(E \cdot L)^{(\beta)} \cdot K^{(1-\beta)}
$$

gdje je $Y$ ukupna proizvodnja (BDP), $L$ je input rada, $K$ je fiksni kapital, a $E$ tehnički napredak koji unaprjeđuje rad, tzv. Harrodov neutralni tehnički napredak. Parametri $\beta$ i $1-\beta$ predstavljaju koeficijente elastičnosti proizvodnje u odnosu na rad i u odnosu na kapital. Izraz $E \cdot L$ može se interpretirati kao input rada korigiran za učinkovitost. Ukupna proizvodnost rada (TFP) i tehnički napredak koji unaprjeđuje rad povezani su relacijom TFP $=E^{\beta}$, pri čemu je $\beta$ udio troškova rada u ukupnoj bruto dodanoj vrijednosti. Prema različitim istraživanja ovaj pokazatelj se najčešće u europskim dokumentima koji proučavaju potencijalni output određuje na razini oko 0,65 (European Commission, 2017).

Prema standardnom neoklasičnom Solowljevom modelu rasta (Solow, 1956) gospodarstvo će postići točku ravnoteže u trenutku kad omjer kapitala i rada korigiranog za učinkovitost tijekom vremena teži konstanti. Rast proizvodnosti rada je u tom slučaju jednak rastu TFP podijeljenom s udjelom rada u bruto dodanoj vrijednosti. U kratkom roku sve su od gore navedenih varijabli podložne promjenama u gospodarstvu, odnosno fazi gospodarskog ciklusa. Stoga se u kratkoročnim prognozama najčešće kao pokazatelj potencijalnog outputa koristi samo komponenta trenda, dok se kapital uzima kao nepromjenjiv, odnosno ciklička komponenta se izdvaja kako iz TFP tako i iz proizvodnih faktora. Trend TFP se izračunava pomoću određenih tehnika desezoniranja koje se često koriste u ekonomskim istraživanjima.

Za razliku od kratkoročnog razdoblja u kojem kretanje potražnje i drugi faktori iz okružja dovode do mogućnosti cikličkog odstupanja stvarnog BDP-a od potencijalnog, u dugom roku rast realnog gospodarstva određen je kretanjem obujma i kvalitete proizvodnih faktora. Radi usporedivosti s rezultatima drugih članica EU, metodologija projekcija u ovom radu za izračun potencijalnog BDP-a za RH u velikoj se mjeri temelji na pretpostavkama prikazanim u European Commission (2017). Očekivani prosječni godišnji rast gospodarske aktivnosti ovisi o sljedećim faktorima:

- kretanju zaposlenosti: očekivano kretanje inputa rada određeno je promjenama dobno-spolnih skupina prema demografskim projekcijama, te kretanjem stopa participacije i stope nezaposlenosti;

- promjeni kapitala;

- kretanju ukupne proizvodnosti faktora proizvodnje (TFP). 


\section{Pretpostavke i koraci u izradi gospodarskih projekcija za Republiku Hrvatsku}

Nastavno na metodologiju prikazanu u prethodnom poglavlju u ovom su dijelu opisane korištene pretpostavke za svaku projekciju pojedinih čimbenika dugoročnog rast. To obuhvaća projekcije kretanja aktivnosti stanovništva i zaposlenosti, projekcije proizvodnosti rada kao funkcije prirasta kapitala i rasta ukupne proizvodnosti faktora proizvodnje (TFP), te u konačnici projekcije BDP-a kao rezultat svih prethodnih projekcija pojedinih varijabli. Rezultati projekcija i njihova analiza prikazani su u poglavlju 5 .

\subsection{Projekcija kretanja aktivnosti stanovnišstva i zaposlenosti}

Za projekciju kretanja aktivnosti stanovništva i zaposlenosti korištene su Demografske projekcije čije su pretpostavke i rezultati opisani u EIHP (2018) i dostupni u tri scenarija. Bez obzira na različite scenarije, osnovni rezultati ukazuju na značajno smanjenje broja hrvatskih rezidenata u razdoblju do 2050. godine i na povećanje udjela stanovništva iznad 65 godina na uštrb smanjenja udjela dobnospolnih skupina s visokim stopama aktivnosti u ukupnom stanovništvu.

Projekcija radne snage, odnosno aktivnog stanovništva temelji se na pretpostavkama o kretanju stopa aktivnosti po pojedinim dobnim skupinama. U projekcijama se polazi od činjenice da RH trenutno ima znatno niže stope ekonomske aktivnosti stanovništva od većine zemalja EU, pa se pretpostavlja da će stope aktivnosti po dobnim skupinama i po spolu konvergirati stopama koje su zabilježene posljednjih godina za prosjek EU27, točnije da će one u RH rasti. Slična pretpostavka primijenjena je i u europskim dokumentima u kojima su prikazane dugoročne projekcije. Međutim, valja naglasiti da će stope aktivnosti i u drugim zemljama EU rasti zbog izbjegavanja negativnih gospodarskih učinaka starenja stanovništva, te da izjednačavanje sa sadašnjim stopama aktivnosti zemalja EU i dalje ostavlja određenu razliku u stopama aktivnosti u RH i EU u cijelom projiciranom razdoblju do 2050. godine.

Povezivanje projekcija radne snage i zaposlenosti postiže se pretpostavkama vezanim za kretanje stope nezaposlenosti. Obično se pretpostavlja da će stopa nezaposlenosti vremenom konvergirati stopi strukturne nezaposlenosti. Prema pretpostavkama korištenima u europskim projekcijama stopa nezaposlenosti u RH će se smanjivati prema dugoročnoj strukturnoj stopi nezaposlenosti tokom cijelog razdoblja, te bi do 2050. godine stopa nezaposlenosti iznosila 7,5 posto. Dinamika smanjenja stope nezaposlenosti brža je u ranijim razdobljima. U skladu s novijim 
podacima o kretanju na tržištu rada, može se uočiti da je zbog emigracije dijela stanovništva u radnoj dobi i oporavka gospodarstva, dinamika smanjenja stope nezaposlenosti znatno brža od dinamike predviđene u europskim projekcijama. Stoga je radna pretpostavka korištena u ovom radu da će stopa nezaposlenosti padati do 2030. godine do 7 posto, a nakon čega će se tek blago smanjivati i doseći 6 posto krajem projiciranog razdoblja.

Broj zaposlenih u RH projiciran je na osnovi demografskih projekcija, a uz spomenute pretpostavke vezane za stopu aktivnosti i stopu nezaposlenosti. Kako postoje tri verzije demografskih projekcija, ovisno o alternativnim pretpostavkama o budućim stopama fertiliteta i salda migracija, tako su i projekcije aktivnog stanovništva i broja zaposlenih u nastavku prikazane u tri varijante.

\subsection{Projekcija proizvodnosti rada kao funkcije kretanja kapitalne opremljenosti rada i ukupne faktorske proizvodnosti}

Zbog očekivanih nepovoljnih demografskih kretanja u RH, ali i velikom broju zemalja članica EU, potencijalni rast BDP-a u budućem dugoročnom razdoblju gotovo će u cijelosti ovisiti o rastu proizvodnosti rada. Europske projekcije predviđaju prosječan godišnji porast proizvodnosti rada od 0,9 do 1,5 posto za EU28 do 2030. uz značajne razlike po pojedinim zemljama. U načelu bi porast proizvodnosti trebao biti glavni faktor konvergencije. U tom razdoblju, najviše stope rasta proizvodnosti rada (veće od 3 posto godišnje) očekivane su za najmanje razvijene zemlje poput Bugarske i Rumunjske. Ostale zemlje nove članice također bi trebale ostvariti brži rast proizvodnosti rada u odnosu na prosjek EU ostvarujući prosječno dvostruko veće stope rasta.

Jedina nova članica za koju se, prema europskim projekcijama, (European Commission, 2017) ne očekuje rast proizvodnosti brži od prosjeka EU jest RH gdje bi proizvodnost u razdoblju 2021.-2040. trebala prosječno godišnje rasti 1,4 posto, a što je istovremeno i prosjek rasta proizvodnosti u EU. Prema projekcijama, oko dvije trećine rasta proizvodnosti rada može se objasniti kretanjem TFP. Na razini cijele EU predviđen je porast doprinosa rasta TFP sa oko 0,6 postotnih bodova godišnje (razdoblje 2016.-2020.) do 1 postotni bod prosječno godišnje (u razdoblju od 2030 do kraja projiciranog razdoblja). Zemlje nove članice ostvarit ce prosječno dvostruko brži rast TFP, dok je rast TFP u RH u navedenom dokumentu European Commission (2017) procijenjen na razinu ispod prosjeka EU (Tablica 1). 
Tablica 1.

GODIŠNJA STOPA RASTA UKUPNE FAKTORSKE PROIZVODNOSTI, PROSJEK RAZDOBLJA

\begin{tabular}{|c|c|c|c|c|c|c|c|}
\hline & $\begin{array}{l}2016 .- \\
2020 .\end{array}$ & $\begin{array}{l}\text { 2021.- } \\
2030 .\end{array}$ & $\begin{array}{l}\text { 2031.- } \\
2040 .\end{array}$ & $\begin{array}{l}2041 .- \\
2050 .\end{array}$ & $\begin{array}{l}2051 .- \\
2060 .\end{array}$ & $\begin{array}{l}\text { 2061.- } \\
2070 .\end{array}$ & $\begin{array}{l}2016 .- \\
2070 .\end{array}$ \\
\hline Belgija & 0.4 & 0.6 & 0.8 & 1.0 & 1.0 & 1.0 & 0.8 \\
\hline Bugarska & 1.6 & 1.7 & 1.6 & 1.5 & 1.3 & 1.1 & 1.4 \\
\hline Češka & 1.2 & 1.4 & 1.3 & 1.2 & 1.1 & 1.0 & 1.2 \\
\hline Danska & 0.5 & 0.8 & 0.9 & 1.0 & 1.0 & 1.0 & 0.9 \\
\hline Njemačka & 0.9 & 0.9 & 0.9 & 1.0 & 1.0 & 1.0 & 1.0 \\
\hline Estonija & 1.0 & 1.2 & 1.3 & 1.2 & 1.2 & 1.0 & 1.2 \\
\hline Irska & 1.8 & 1.2 & 0.9 & 1.0 & 1.0 & 1.0 & 1.1 \\
\hline Grčka & -0.3 & 0.3 & 0.8 & 1.2 & 1.2 & 1.0 & 0.8 \\
\hline Španjolska & 0.4 & 0.6 & 0.8 & 1.0 & 1.0 & 1.0 & 0.9 \\
\hline Francuska & 0.4 & 0.6 & 0.8 & 1.0 & 1.0 & 1.0 & 0.8 \\
\hline Hrvatska & 0.4 & 0.6 & 1.0 & 1.3 & 1.2 & 1.1 & 1.0 \\
\hline Italija & -0.1 & 0.2 & 0.6 & 1.0 & 1.0 & 1.0 & 0.7 \\
\hline Cipar & -0.1 & 0.2 & 0.6 & 1.1 & 1.1 & 1.0 & 0.7 \\
\hline Latvija & 3.2 & 3.0 & 1.8 & 1.4 & 1.2 & 1.1 & 1.8 \\
\hline Litva & 0.7 & 1.4 & 1.4 & 1.3 & 1.1 & 1.0 & 1.2 \\
\hline Luksemburg & 0.6 & 0.9 & 1.0 & 1.0 & 1.0 & 1.0 & 0.9 \\
\hline Madžarska & 1.0 & 1.4 & 1.5 & 1.3 & 1.2 & 1.1 & 1.3 \\
\hline Malta & 1.7 & 1.6 & 1.3 & 1.1 & 1.0 & 1.0 & 1.2 \\
\hline Nizozemska & 0.3 & 0.5 & 0.8 & 1.0 & 1.0 & 1.0 & 0.8 \\
\hline Austrija & 0.6 & 0.8 & 0.9 & 1.0 & 1.0 & 1.0 & 0.9 \\
\hline Poljska & 1.3 & 1.7 & 1.5 & 1.3 & 1.2 & 1.1 & 1.3 \\
\hline Portugal & 0.6 & 0.8 & 1.0 & 1.2 & 1.1 & 1.0 & 1.0 \\
\hline Rumunjska & 2.7 & 2.5 & 1.7 & 1.4 & 1.2 & 1.1 & 1.7 \\
\hline Slovenija & 1.1 & 1.4 & 1.3 & 1.2 & 1.1 & 1.0 & 1.2 \\
\hline Slovačka & 2.1 & 2.3 & 1.7 & 1.2 & 1.1 & 1.0 & 1.5 \\
\hline Finska & 0.1 & 0.5 & 0.8 & 1.0 & 1.0 & 1.0 & 0.8 \\
\hline Švedska & 0.9 & 0.9 & 0.9 & 1.0 & 1.0 & 1.0 & 1.0 \\
\hline $\begin{array}{l}\text { Velika } \\
\text { Britanija }\end{array}$ & 0.5 & 0.8 & 0.9 & 1.0 & 1.0 & 1.0 & 0.9 \\
\hline Norveška & 0.6 & 0.8 & 0.9 & 1.0 & 1.0 & 1.0 & 0.9 \\
\hline EU28 & 0.6 & 0.8 & 1.0 & 1.0 & 1.0 & 1.0 & 0.9 \\
\hline $\begin{array}{l}\text { EU27 (bez } \\
\text { Velike } \\
\text { Britanije) } \\
\end{array}$ & 0.6 & 0.8 & 1.0 & 1.1 & 1.0 & 1.0 & 0.9 \\
\hline
\end{tabular}

Izvor: European Commision (2017) 
U pogledu doprinosa kapitalne opremljenosti rada, pretpostavljeno je da će doprinos rasta kapitala u zemljama EU konvergirati prema ravnotežnoj vrijednosti od 0,5 posto zbog pretpostavke o prilagodbi kretanju faktora rad. Doprinos kapitala u demografskim projekcijama za RH procijenjen je na nešto višu razinu u odnosu na prosjek EU. Projekcije proizvodnosti rada u ovom radu napravljene su prema dva scenarija:

a) bazni scenarij kod kojeg se koristi očekivani rast ukupne proizvodnosti faktora, te kapitalne opremljenosti rada kao u europskim projekcijama;

b) scenarij konvergencije kod kojeg je rast kapitalne opremljenosti rada preuzet iz europskih projekcija, dok je pretpostavljeno uspješno provođenje strukturnih reformi što ce rezultirati konvergenciji rasta TFP prema prosjeku zemalja novih članica EU. Ovakav scenarij bi trebao predstavljati društveno poželjan, ali i ostvariv scenarij.

\subsection{Projekcija BDP-a na razini $R H$}

Projekcije gospodarskog rasta za RH rezultat su projekcija prethodno opisanih osnovnih inputa: demografskih kretanja, ukupne faktorske proizvodnosti i kapitalne opremljenosti rada. Projicirana stopa rasta BDP-a za svaku godinu je prema ranije opisanoj metodologiji jednaka zbroju rasta inputa rada i proizvodnosti rada. Proizvodnost rada je rezultat očekivanog rasta TFP i kapitalne opremljenosti. Budući postoje različite kombinacije demografskih projekcije (EIHP 2018, 3 alternativne varijante) i projekcija TFP (dvije alternative varijante) razvidno je da je moguće napraviti šest scenarija gospodarskog razvitka. U ovom radu su razrađena dva scenarija dinamike gospodarskog rasta u RH do 2050. godine koja su najbliže realnom ostvarenju:

Scenarij 1: Niska demografska projekcija uz baznu TFP - tzv. bazni scenarij

Scenarij 2: Srednja demografska projekcija uz postojanje konvergencije TFP - tzv. poželjan, ali ostvariv scenarij

Scenarij 1 je nepovoljniji scenarij koji kombinira nepovoljna demografskih kretanja i nastavak dosadašnjeg trenda u kretanju TFP. On opisuje status quo gospodarskih i društvenih procesa u RH. Taj scenarij rezultira izostankom bilo kakve konvergencije TFP-a, ali i razine standarda, prema prosjeku EU. On znači daljnje produbljivanje jaza za svim novim članicama i donosi RH začelje prema razini razvijenosti mjereno BDP-om pc u EU. S druge strane, nešto manje nepovoljna demografska kretanja (Scenarij 2) i brži rast TFP prema razini proizvodnosti koju 
bilježe NMS-12 ${ }^{1}$, predstavlja optimističnu verziju, ostvariv scenarij i zavisi u velikoj mjeri o ustrajnosti nositelja ekonomske vlasti na provedbi reformi kojima bi se stvorili uvjeti za ubrzani rast proizvodnosti.

\subsection{Ograničenja pri izradi gospodarskih projekcija}

Dugoročne projekcije trendova u kretanju pojedinih djelatnosti nacionalnog gospodarstva najčešće su praćene izrazito visokim potencijalnim greškama procjene. Razdoblje liberalizacije međunarodne razmjene, globalizacije gospodarstva i ubrzanih promjena u tehnologijama, samo su neki od razloga za dinamičnu promjenu strukture nacionalnih gospodarstava. U uvjetima slobodnog kretanja roba, rada i kapitala, postojeća gospodarska struktura i raspoloživost prirodnih resursa više nisu faktori koji najznačajnije utječu na specijalizaciju u proizvodnji i međunarodnoj razmjeni. Povoljno institucionalno okružje sve više postoje presudno za privlačenje investicija, novih tehnologija i transformaciju gospodarstva u sektore s višom dodanom vrijednošću.

Standardni ekonometrijski modeli kvantificiraju međuzavisnost u kretanju zavisnih i nezavisnih varijabli pod pretpostavkom da ostale varijable koje nisu eksplicitno uključene u model ostaju nepromjenjive. U dugom roku, pretpostavka o nepromjenjivosti takvih varijabli je upitna.

\section{Rezultati istraživanja}

\subsection{Očekivane demografske promjene i utjecaj na kretanje zaposlenosti}

Kao što je ranije navedeno u procjeni potencijalnog BDP-a, polazi se od procjene demografskih kretanja. Demografske projekcije po desetogodišnjim razdobljima, po dobno-spolnim skupinama prikazane su za sva tri demografska scenarija (niski, srednji i visoki) u prilogu u Tablicama P1, P2 i P3. Iako su rezultati pojedinih scenarija različiti, kretanja u svima su nepovoljna. Ukupnom smanjenju broja stanovnika najviše pridonosi stanovništvo u najboljoj radnoj dobi, dok će broj stanovnika u dobi iznad 60 godina rasti. Slika 1 ilustrira promjene u demografskoj strukturi prema srednjem scenariju demografskih projekcija.

1 NMS-12 (eng. New Member States) - kratica za zemlje nove članice EU koje su se pridružile Uniji 2004. i 2007. godine; Bugarska, Cipar, Republika Češka, Estonija, Latvija, Litva, Mađarska, Malta, Poljska, Rumunjska, Slovačka i Slovenija 
Slika 1 .

\section{STAROSNA STRUKTURA STANOVNIŠTVA 2011. I 2051. GODINE PREMA DOBNIM SKUPINAMA}

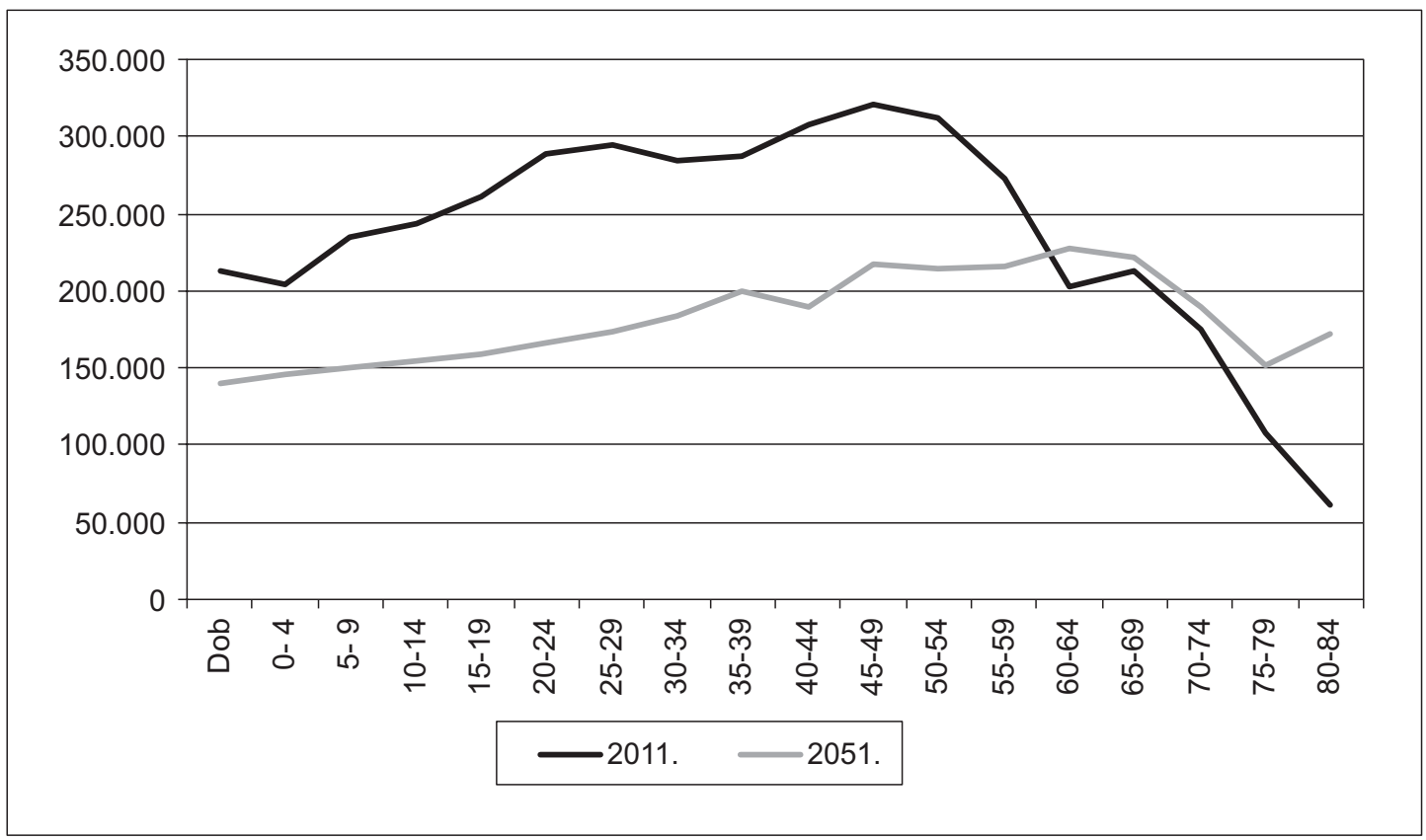

Izvor: EIHP (2018.)

Broj stanovnika u dobi od 15-64 godina, kao pokazatelj potencijalno raspoložive radne snage u projiciranom razdoblju smanjivat će se prosječnom godišnjom dinamikom od $-1,0$ posto. Najveći relativni pad očekuje se upravo za osobe u tzv. prime working age, odnosno u dobi od 25-49 godina. Ukoliko ove projekcije usporedimo s projekcijama koje koristi Europska komisija (European Commission, 2017) u kojima je procijenjeno prosječno godišnje smanjenje broja stanovnika od $-0,8$ posto, može se uočiti da ažurirani podaci korišteni u ovom radu prikazuju izraženiji intenzitet smanjivanja broja stanovnika u radnoj dobi nego što je to predviđala Europska komisija.

Nepovoljna demografska kretanja intenzivno će djelovati na tržište rada neovisno o kojoj je demografskoj projekciji riječ. Nužan uvjet za ostvarenje barem minimalnog razvojnog potencijala jest povećanje stopa participacije svih dobnospolnih skupna. Projekcija očekivane radne snage polazi od stopa aktivnosti po dobnim skupinama, odnosno pretpostavke konvergencije prema stopama aktivnostima koje su trenutno prosječno zabilježene u EU. Najizraženiji zahtjev za povećanjem stopa aktivnosti odnosi se na stanovništvo u starijoj radnoj dobi (50-64 godina) čije su stope aktivnosti u usporedbi s ostalim zemljama EU izrazito niske. 


\section{Tablica 2 .}

\section{PROJICIRANE STOPE PARTICIPACIJE UKUPNE POPULACIJE U RADNOJ DOBI PO DESETOGODIŠNJIM RAZDOBLJIMA U RH}

\begin{tabular}{|c|r|r|r|r|r|c|}
\hline Dobne skupine & 2017. & 2020. & 2030. & 2040. & 2050. & Promjena 2050.-2017. \\
\hline $15-24$ & 35.7 & 36.2 & 38.0 & 39.7 & 41.5 & 5.8 \\
\hline $25-49$ & 85.6 & 85.7 & 86.3 & 86.8 & 87.4 & 1.8 \\
\hline $50-64$ & 53.2 & 54.6 & 59.3 & 63.9 & 68.5 & 15.3 \\
\hline $65+$ & 2.8 & 3.1 & 4.0 & 4.9 & 5.9 & 3.1 \\
\hline $15-64$ & 66.2 & 67.0 & 69.0 & 71.3 & 73.5 & 7.3 \\
\hline
\end{tabular}

Izvor: Projekcije autora.

Usporede li se projicirane stope participacije s europskim projekcijama gdje je krajem projiciranog razdoblja korištena stopa participacije od oko 71 posto za ukupno stanovništvo u dobi od 15 do 64 godina iz Tablice 2. može se uočiti da su ove ažurirane projekcije nešto povoljnije, a razlog je korištenje novijih službenih podataka koji upućuju na poboljšanje na tržištu rada. Noviji podaci također ukazuju na bržu dinamiku smanjivanja stope nezaposlenosti, te je za razliku od europskih projekcija koje predviđaju smanjenje stope nezaposlenosti na 7,5 posto tek krajem projiciranog razdoblja, ovdje pretpostavljeno da će razina nezaposlenosti od 7 posto biti dosegnuta već 2030. godine, nakon čega ostaje na toj razini do kraja projiciranog razdoblja.

Promatraju li se projicirane stope aktivnosti po dobno-spolnim skupinama, može se primijetiti da u svim promatranim dobnim skupinama veći stopu aktivnosti bilježe muškarci (Slika 2). 
Slika 2 .

\section{PROJICIRANE STOPE AKTIVNOSTI PO DOBNO-SPOLNIM SKUPINAMA}

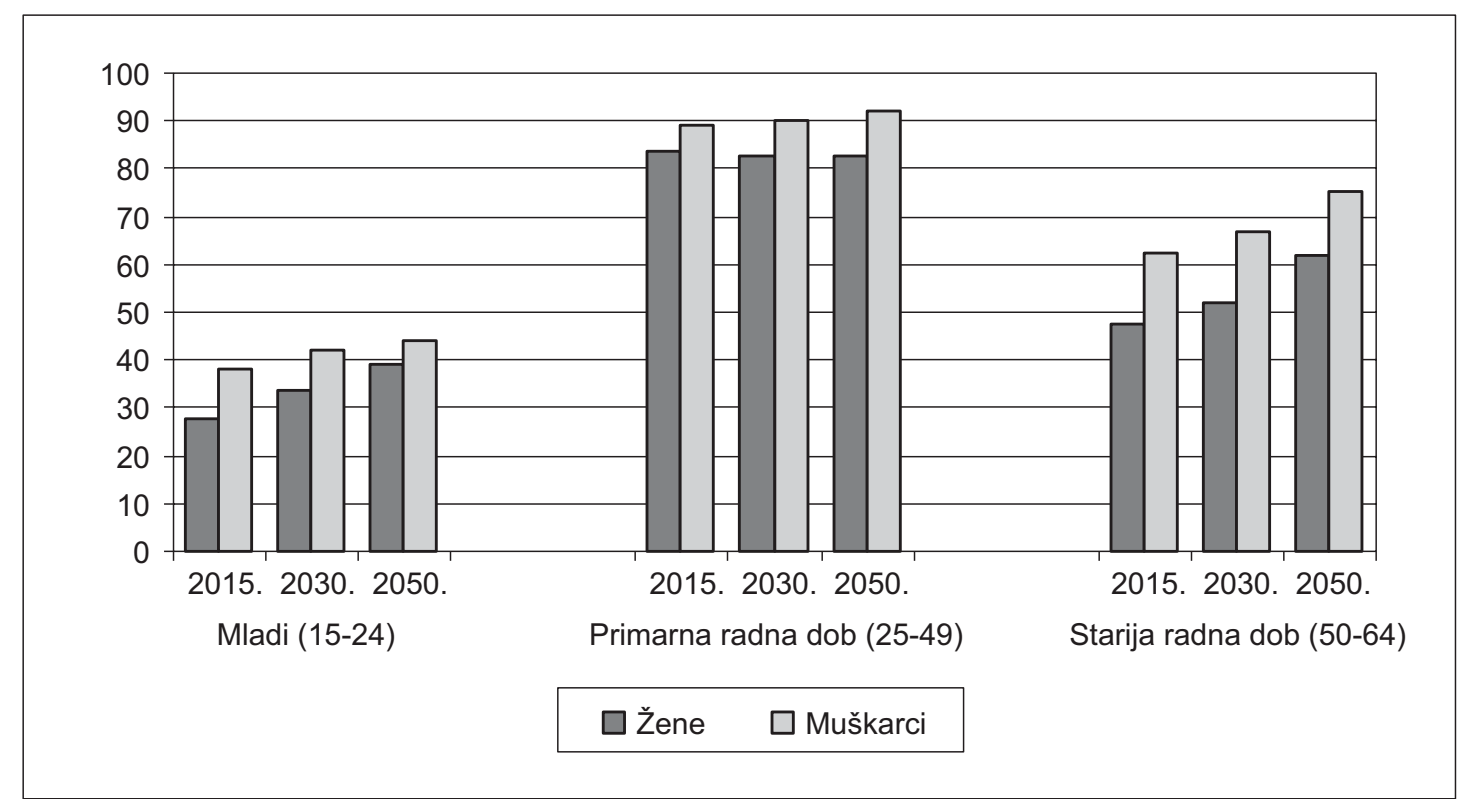

Izvor: Projekcije autora.

\subsection{Očekivano kretanje proizvodnosti rada}

Nakon procjene demografskih kretanja, potrebno je procijeniti kretanje proizvodnosti rada. Kao što je navedeno u prethodnom poglavlju koje opisuje pretpostavke različitih scenarija, proizvodnost rada napravljena je u dvije varijante:

- proizvodnost rada određena je kretanjem kapitalne opremljenosti i TFP dinamikom koja je korištena u europskim projekcijama (European Commission ,2017).

- proizvodnost rada raste bržom dinamikom zbog konvergencije rasta TFP prema prosjeku očekivanom za zemlje članice NMS-12, dok kapitalna opremljenost slijedi dinamiku europskih projekcija za RH. To su projekcije autora koje prikazuju ostvariv i poželjan scenarij. 
Tablica 3.

\section{OČEKIVANI RAST PROIZVODNOSTI RADA PO PODRAZDOBLJIMA}

\begin{tabular}{|l|c|c|c|c|}
\hline & 2021.-2030. & 2031.-2040. & 2041.-2050. & 2016.-2050. \\
\hline $\begin{array}{l}\text { Proizvodnost rada (bazna) -EC } \\
\text { projekcije }\end{array}$ & 1.3 & 1.6 & 2.0 & 1.6 \\
\hline TFP (bazna) -EC projekcije & 0.6 & 1.0 & 1.3 & 1.0 \\
\hline Kapitalna opremljenost-EC projekcije & 0.7 & 0.5 & 0.7 & 0.7 \\
\hline $\begin{array}{l}\text { Proizvodnost rada (pretpostavka } \\
\text { konvergencija prema NMS - 12) - } \\
\text { projekcije autora }\end{array}$ & 2.6 & 2.3 & 2.3 & 2.4 \\
\hline $\begin{array}{l}\text { TFP (pretpostavka konvergencija prema } \\
\text { NMS -12) - projekcije autora }\end{array}$ & 1.9 & 1.8 & 1.6 & 1.8 \\
\hline $\begin{array}{l}\text { Kapitalna opremljenost- projekcije } \\
\text { autora, ista kao i EC projekcije }\end{array}$ & 0.7 & 0.5 & 0.7 & 0.7 \\
\hline
\end{tabular}

Izvor: European Commission (2017); projekcije autora.

Sve pretpostavke baznog scenarija kretanja proizvodnosti rada preuzete su iz europskih projekcija i mogu se detaljnije vidjeti u prethodnom poglavlju, odnosno European Commission (2017). Valja napomenuti da podizanje TFP na prosječnu razinu koju ostvaruju zemlje NMS-12, a posebice kad je riječ o zahtjevu za dugoročnim osiguranjem uvjeta za rast konkurentnosti gospodarstva i proizvodnosti rada ovisi o dinamici i učinkovitosti provođenja strukturnih reformi.

Prema baznom scenariju kretanja proizvodnosti rada razvidno je da je RH u usporedbi s drugim zemljama EU loše pozicionirana, a ponajviše zbog nepovoljnije brzine rasta ukupne proizvodnosti faktora (Tablica 1). Ukupan BDP nije rezultat rasta proizvodnosti već kapitalne opremljenosti. To znači da zemlja troši puno kapitala uz malen učinak, odnosno da se investicije događaju u sektorima s niskom proizvodnošću (turizam, trgovina i usluge) ili vrlo dugim razdobljima povrata (infrastrukturne investicije). Prema scenariju konvergencije TFP koji je prema mišljenju autora dostižan uz napor svih društvenih skupina, uz istu kapitalnu opremljenost, proizvodnost rada će rasti brže prema prosjeku zemalja NMS-12. 


\subsection{Varijantne projekcije kretanja BDP-a}

Ovisno o varijantnim scenarijima demografskih projekcija (3 demografske projekcije) i kretanja proizvodnosti (2 projekcije iz prethodnog poglavlja), postoji 6 različitih scenarija kretanja BDP-a do 2050. godine. Za svaku demografsku projekciju, odgovarajuce tablice prikazuju rezultate prema dva scenarija: bazna proizvodnost TFP i konvergencija proizvodnosti TFP.

\subsubsection{Projekcije kretanja BDP-a temeljem niskih demografskih projekcija - scenarij 1}

Slika 3.

PROJICIRANE RAZINE (LIJEVA SKALA) I STOPE RASTA BDP-A (DESNA SKALA) TEMELJEM NISKIH DEMOGRAFSKIH PROJEKCIJA - SCENARIJ 1

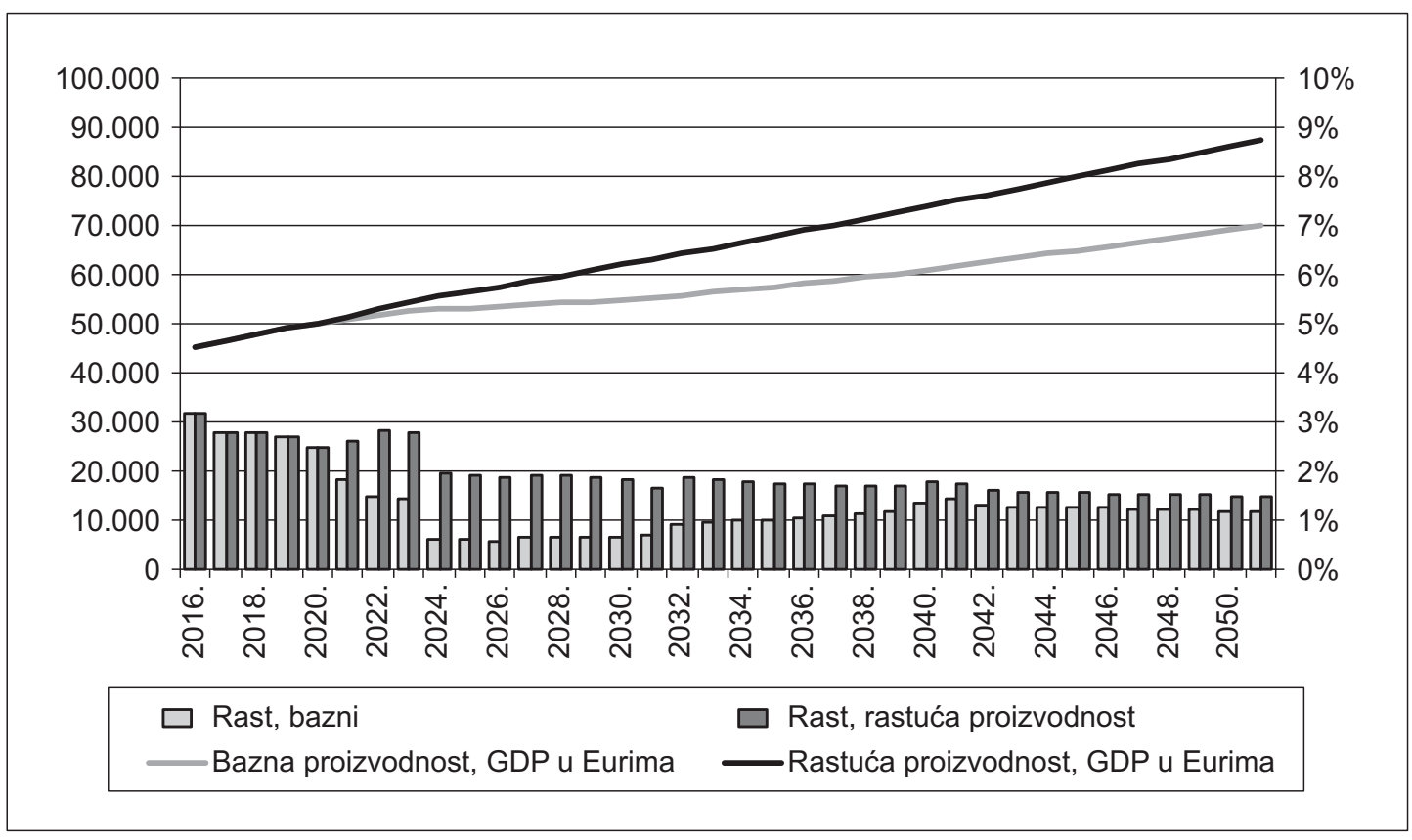

Izvor: Projekcije autora.

Slika 3. prikazuje projicirane stope BDP-a temeljem niskih demografskih projekcija, tzv. scenarij 1, koji je ujedno i scenarij status quo društvenog razvitka 
RH. Može se uočiti da za razliku od bazne proizvodnosti korištene u European Commission (2017), u razdoblju od 2021. do 2040. primjena alternativnog scenarija s višom razinom proizvodnosti rezultira višim stopama rasta BDP-a, što posebice dolazi do izražaja u razdoblju do 2030. godine. Naime, to razdoblje bi RH mogla iskoristiti za transformaciju gospodarstva i smanjenja jaza proizvodnosti prema drugim NMS-12, te time omogućiti brži rast iza 2030. godine.

Ukoliko se ostvare niske demografske projekcije uz odsutnost konvergencije kao što to predviđa European Commission (2017), BDP RH će 2050. godine dosegnuti tek nešto više od 50 posto veću razinu u odnosu na 2016. godinu. S druge strane, uz povećanje proizvodnosti, BDP bi se u istom projiciranom razdoblju udvostručio. BDP iskazan po broju stanovnika raste bržom dinamikom zbog očekivanog smanjenja populacije (Tablica 4).

\section{Tablica 4 .}

PROJEKCIJE BDP-A TEMELJEM NISKIH DEMOGRAFSKIH PROJEKCIJA (BAZNI SCENARIJ -SCENARIJ 1)

\begin{tabular}{|l|c|c|c|c|c|c|}
\hline & $\mathbf{2 0 1 6}$. & $\mathbf{2 0 2 0 .}$ & $\mathbf{2 0 3 0 .}$ & $\mathbf{2 0 4 0 .}$ & $\mathbf{2 0 5 0}$ \\
\hline & \multicolumn{5}{|c|}{ Bazna proizvodnost } \\
\hline GDP, stalne cijene 2010, milijuni HRK & 335,902 & 373,595 & 408,960 & 453,582 & 514,246 \\
\hline GDP, indeks, 2016=100 & 100.0 & 111.2 & 121.7 & 135.0 & 153.1 \\
\hline GDP per capita, stalne cijene 2010 & 82 & 94 & 109 & 130 & 160 \\
\hline GDP per capita, indeks 2016=100 & 100.0 & 114.5 & 133.5 & 158.8 & 195.3 \\
\hline Broj stanovnika, u milijunima & 4,099 & 3,981 & 3,737 & 3,486 & 3,212 \\
\hline $\begin{array}{l}\text { Broj zaposlenih, konstantna aktivnost } \\
\text { stanovništva, u milijunima }\end{array}$ & 1,550 & 1,559 & 1,434 & 1,312 & 1,177 \\
\hline & \multicolumn{5}{|c|}{ Konvergencija proizvodnosti } \\
\hline GDP, stalne cijene 2010, milijuni HRK & 335,902 & 373,595 & 462,081 & 550,017 & 642,163 \\
\hline GDP, indeks, 2016=100 & 100.0 & 111.2 & 137.6 & 163.7 & 191.2 \\
\hline GDP per capita, stalne cijene 2010 & 82 & 94 & 124 & 158 & 200 \\
\hline GDP per capita, indeks 2016=100 & 100.0 & 114.5 & 150.9 & 192.5 & 243.9 \\
\hline Broj stanovnika, u milijunima & 4,099 & 3,981 & 3,737 & 3,486 & 3,212 \\
\hline $\begin{array}{l}\text { Broj zaposlenih, rastuća aktivnost } \\
\text { stanovništva, u milijunima }\end{array}$ & 1,550 & 1,576 & 1,502 & 1,426 & 1,326 \\
\hline
\end{tabular}

Izvor: Projekcije autora. 


\subsubsection{Projekcije kretanja BDP-a na temelju srednjih demografskih projekcija-scenarij 2}

Korištenjem demografskih projekcija koje podrazumijevaju srednju dinamiku kretanja stanovništva, projicirane stope BDP-a tek su nešto veće u usporedbi s niskim demografskim projekcijama (Slika 4). Pretpostavke o proizvodnosti su ključne jer srednji scenarij demografskih projekcija podrazumijeva tek 30 -ak tisuća ljudi više u radnoj dobi, te je doprinos faktora rada tek nešto manje negativan u usporedbi s scenarijem niskih demografskih projekcija.

Slika 4.

PROJICIRANE RAZINE (LIJEVA SKALA) I STOPE RASTA BDP-A (DESNA SKALA) TEMELJEM SREDNJIH DEMOGRAFSKIH PROJEKCIJA I BAZNE PROIZVODNOSTI, ODNOSNO SREDNJIH DEMOGRAFSKIH PROJEKCIJA I RASTUĆE PROIZVODNOSTI

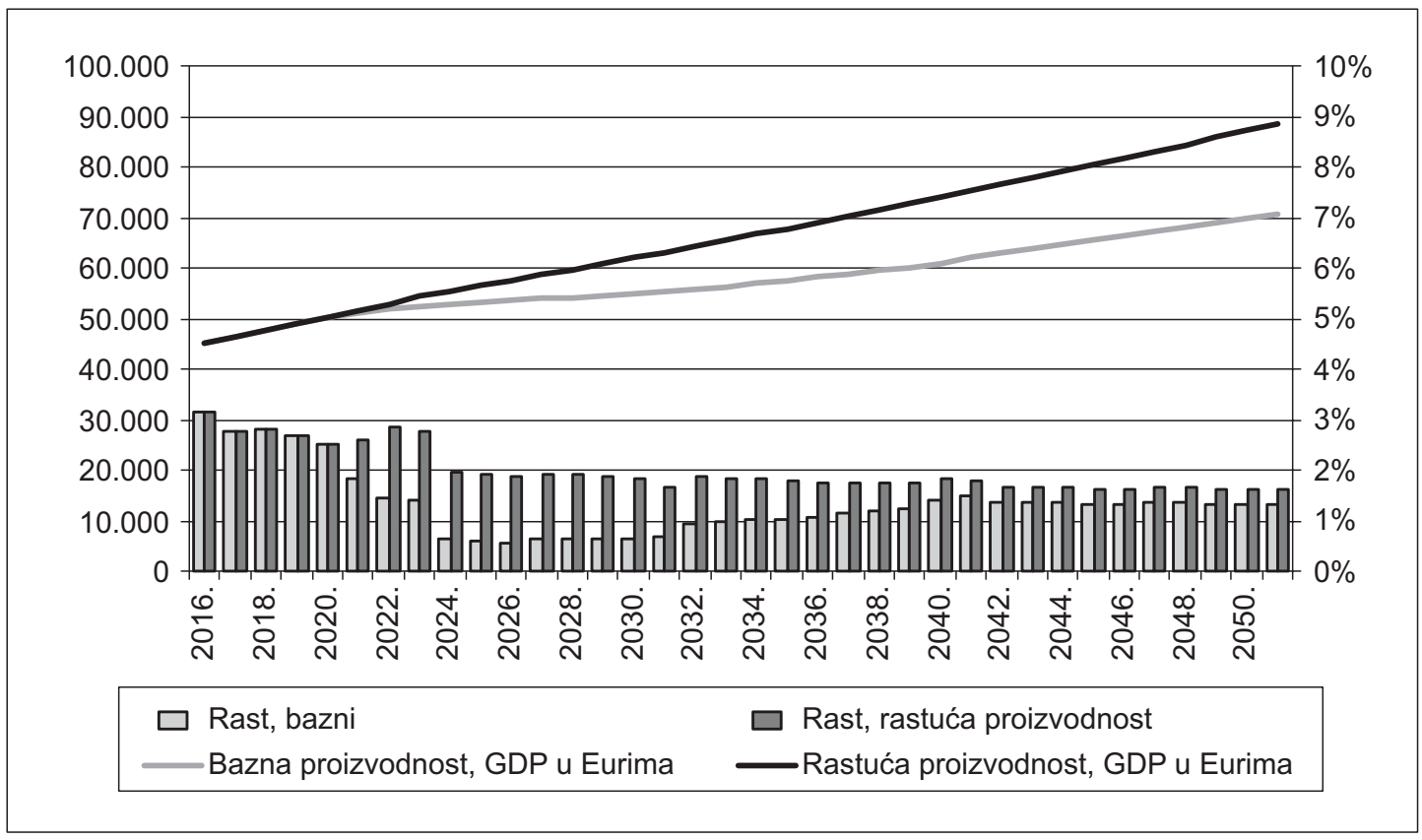

Izvor: Projekcije autora. 


\section{Tablica 5 .}

\section{PROJEKCIJE BDP-A TEMELJEM SREDNJIH DEMOGRAFSKIH PROJEKCIJA I RASTUĆE PROIZVODNOSTI - SCENARIJ 2 - OSTVARIV I POŽELJAN SCENARIJ}

\begin{tabular}{|l|c|c|c|c|c|}
\hline & $\mathbf{2 0 1 6 .}$ & $\mathbf{2 0 2 0 .}$ & $\mathbf{2 0 3 0 .}$ & $\mathbf{2 0 4 0 .}$ & $\mathbf{2 0 5 0 .}$ \\
\hline & \multicolumn{5}{|c|}{ Konvergencija proizvodnosti (scenarij 2) } \\
\hline GDP, stalne cijene 2010, milijuni HRK & 335,902 & 373,595 & 462,111 & 551,311 & 649,695 \\
\hline GDP, indeks, 2016=100 & 100.0 & 111.2 & 137.6 & 164.1 & 193.4 \\
\hline GDP per capita, stalne cijene 2010 & 82 & 94 & 123 & 156 & 197 \\
\hline GDP per capita, indeks 2016=100 & 100.0 & 114.4 & 150.2 & 190.5 & 240.6 \\
\hline Broj stanovnika, u milijunima & 4,099 & 3,984 & 3,755 & 3,532 & 3,295 \\
\hline $\begin{array}{l}\text { Broj zaposlenih, rastuća aktivnost } \\
\text { stanovništva, u milijunima }\end{array}$ & 1,550 & 1,576 & 1,502 & 1,429 & 1,342 \\
\hline
\end{tabular}

Izvor: Projekcije autora.

Ukoliko se ostvare srednje demografske projekcije uz rastuću proizvodnost BDP RH će 2050. godine dosegnuti 93,4 posto (Tablica 5, indeks 193,4) veću razinu u odnosu na 2016. godinu. Blagostanje mjereno BDP per capita indeksom, u usporedbi s 2016. godinom bi trebalo porasti 2,4 puta (indeks 240,6\%). BDP iskazan po broju stanovnika raste bržom dinamikom zbog očekivanog smanjenja populacije. RH će oko 2050. godine imati oko 1.342 tisuća zaposlenih od ukupno 3.295 tisuća stanovnika.

\subsubsection{Sinteza rezultata projekcija rasta BDP-a do 2050. u Republici Hrvatskoj}

Usporedba svih alternativnih scenarija ukazala je na relativno ograničen učinak koje različite demografske projekcije imaju na kretanje BDP-a do 2050. godine. Sve tri varijante demografskih projekcija temeljem uvedenih pretpostavki rezultiraju sa svega 50-60 tisuća razlike u broju zaposlenih krajem projiciranog razdoblja, a što je tek oko 4 posto očekivanog broja zaposlenih između najpovoljnije i najnepovoljnije varijante ${ }^{2}$.

Projekcije razine BDP-a i BDP-a per capita 2050. godine puno više ovise o varijantnim scenarijima u kretanju TFP i posljedično proizvodnosti rada nego o

${ }^{2}$ Varijanta visoke demografske projekcije nije u ovom radu eksplicitno razmatrana jer nije realna EIHP (2018). Razmatrane su niska i srednja varijanta. 
demografskim projekcijama. Stoga je osnovni izazov koji se postavlja pred nositelje ekonomske politike proces osiguranja preduvjeta za brži rast proizvodnosti. U sljedećoj tablici 6. se stoga uspoređuju rezultati dva scenarija, bazni - scenarij 1 (bez TFP konvergencije proizvodnosti, European Commission) i dostižan - scenarij 2 (s konvergencijom TFP proizvodnosti, autor) koji pokazuju donju i gornju granicu potencijalnog outputa u razdoblju do 2050. godine.

Usporedbom s projekcijama Europske komisije može se uočiti da bazni scenarij koji prikazuje donju granicu, odstupa vrlo blago od projekcija Europske komisije samo zbog činjenice da ažurirane demografske projekcije upućuju na moguće veći negativni učinak smanjenja stanovništva radne dobi u početnom razdoblju, jer je Europske komisije koristila službene podatke o broju stanovnika koji su precijenjeni zbog pojave nezabilježene emigracije (EIHP, 2018). Međutim, kao što je već i ranije navedeno, taj scenarij nosi značajan rizik daljnje divergencije RH u odnosu na razvijenost ostalih članica EU27 i posljedično negativnih učinaka starenja na sveukupnu održivost javnih financija i fondova zdravstvenog i mirovinskog osiguranja.

\section{Tablica 6.}

USPOREDBA REZULTATA VARIJANTNIH SCENARIJA RASTA BDP-A

U RAZDOBLJU DO 2050. GODINE, DOPRINOS RAZLIČITIH KOMPONENTI RASTA BDP-A

\begin{tabular}{|c|c|c|c|c|}
\hline & 2021.-2030. & 2031.-2040. & 2041.-2050. & 2021.-2050. \\
\hline & \multicolumn{5}{|c|}{ European Commission (2017) } \\
\hline Rast GDP & 0,8 & 1,4 & 1,7 & $\mathbf{1 , 3}$ \\
\hline Rad & $-0,5$ & $-0,1$ & $-0,3$ & $-0,4$ \\
\hline Kapital & 0,7 & 0,5 & 0,7 & 0,7 \\
\hline TFP & 0,6 & 1,0 & 1,3 & 1,0 \\
\hline \multicolumn{5}{|c|}{ Niska demografska projekcija, bazna TFP - bazni scenarij, scenarij 1, } \\
\hline \multicolumn{5}{|c|}{ autor } \\
\hline Rast GDP & 0.9 & 1.0 & 1.3 & $\mathbf{1 . 1}$ \\
\hline Rad & -0.5 & -0.5 & -0.7 & -0.6 \\
\hline Kapital & 0,7 & 0,5 & 0,7 & 0,7 \\
\hline TFP & 0.6 & 1.0 & 1.3 & 1.0 \\
\hline \multicolumn{5}{|c|}{ Srednja demografska projekcija, konvergencija TFP - dostižan scenarij, } \\
\hline Rast GDP & 2.2 & 1.8 & 1.7 & $\mathbf{1 . 9}$ \\
\hline Rad & -0.5 & -0.5 & -0.6 & -0.5 \\
\hline Kapital & 0,7 & 0,5 & 0,7 & 0,7 \\
\hline TFP & 1.9 & 1.8 & 1.6 & 1.8 \\
\hline
\end{tabular}

Izvor: Projekcije autora. 
Slike 5 i 6 prikazuju dekompoziciju rasta BDP-a na osnovne izvore rasta: input rada, kapitalnu opremljenost i ukupnu faktorsku proizvodnost. Kao što je razvidno iz slika osnovna razlika iz pojedinih scenarija rasta proizlazi iz kretanja TFP, dok su kapital i input rada manje značajni za stvaranje razlike među scenarijima rasta.

\section{Slika 5 .}

\section{DEKOMPOZICIJA RASTA BDP-A PO PODRAZDOBLJIMA, NISKE DEMOGRAFSKE PROJEKCIJE, BAZNA PROIZVODNOST (BAZNI SCENARIJ -1)}

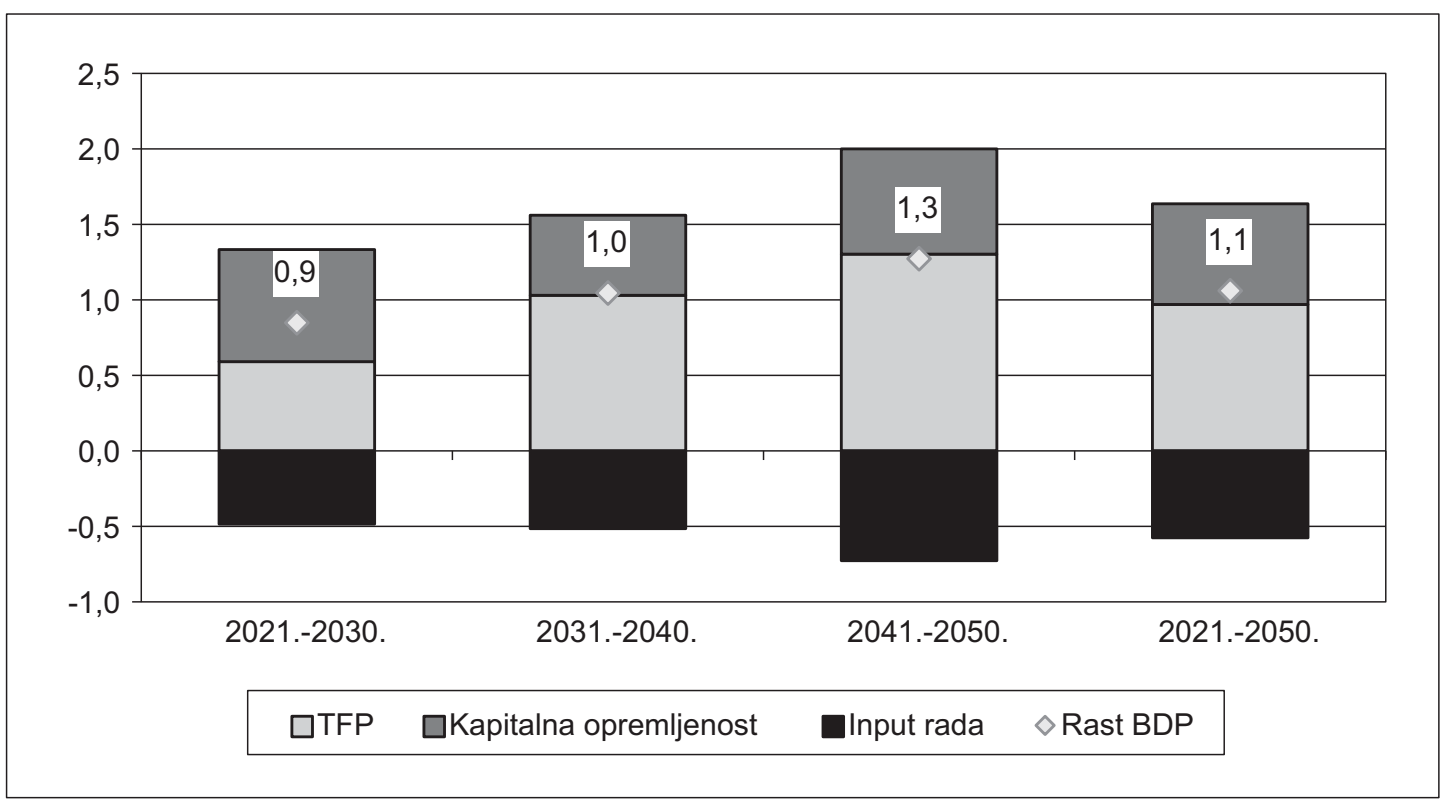

Izvor: Projekcije autora. 
Slika 6.

\section{DEKOMPOZICIJA RASTA BDP-A PO PODRAZDOBLJIMA, SREDNJE DEMOGRAFSKE PROJEKCIJE, SCENARIJ KONVERGENCIJA PROIZVODNOSTI - SCENARIJ 2, DOSTIŽAN SCENARIJ}

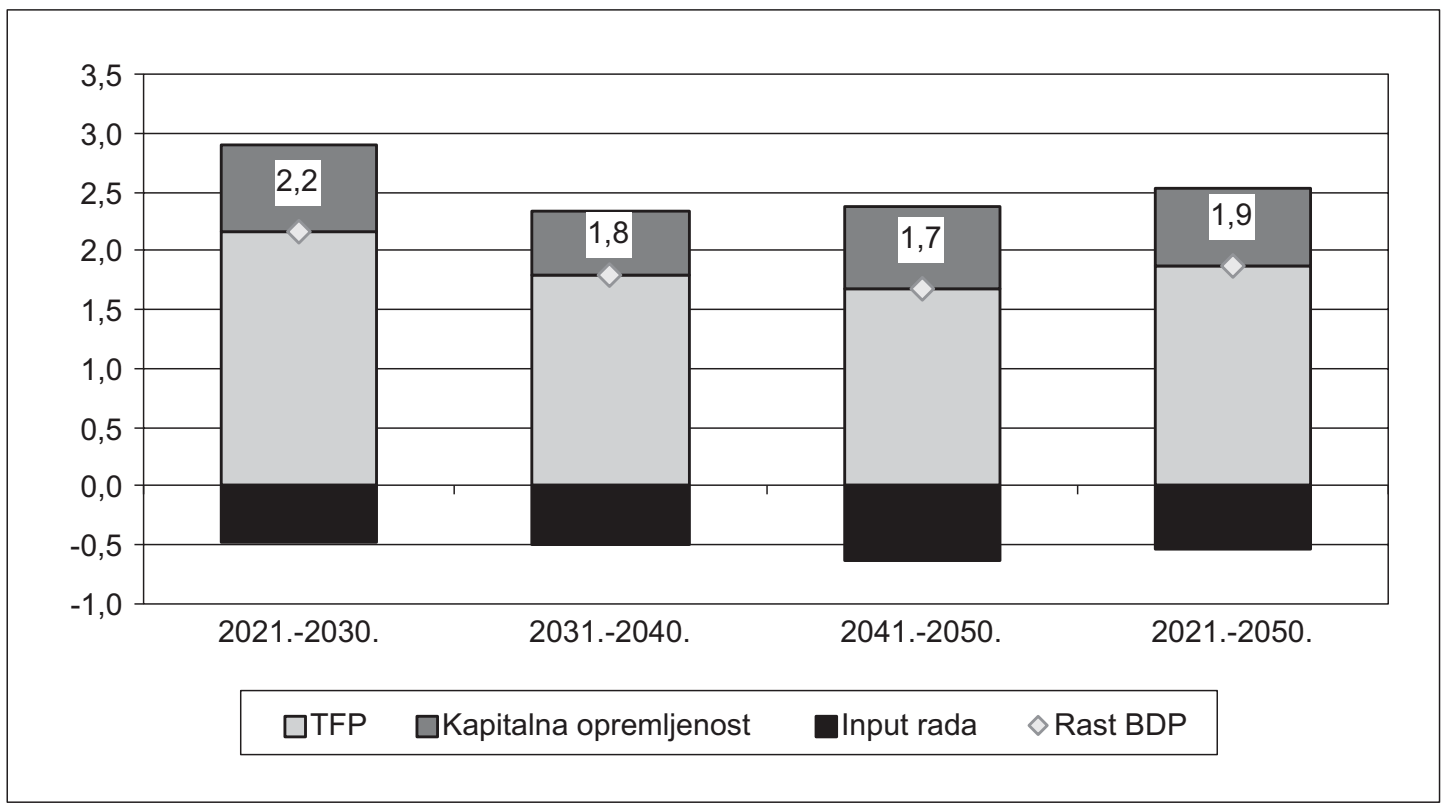

Izvor: Projekcije autora.

Usporedba projekcija Europske komisije i dva alternativna scenarija prikazana je Slikom 7. Može se uočiti da scenarij niske demografije (scenarij 1) krajem razdoblja dosiže razinu BDP-a koja je i projicirana u dokumentu Europske komisije. Ostvaren je nešto brži rast BDP-a od očekivanog prema konceptu potencijalnog outputa tijekom prošle i ove godine, ali uz bazni scenarij kretanja proizvodnosti. 


\section{Slika 7.}

\section{USPOREDBA DOSEGNUTE RAZINE REALNOG BDP-A, INDEKS 2016 $=100$}

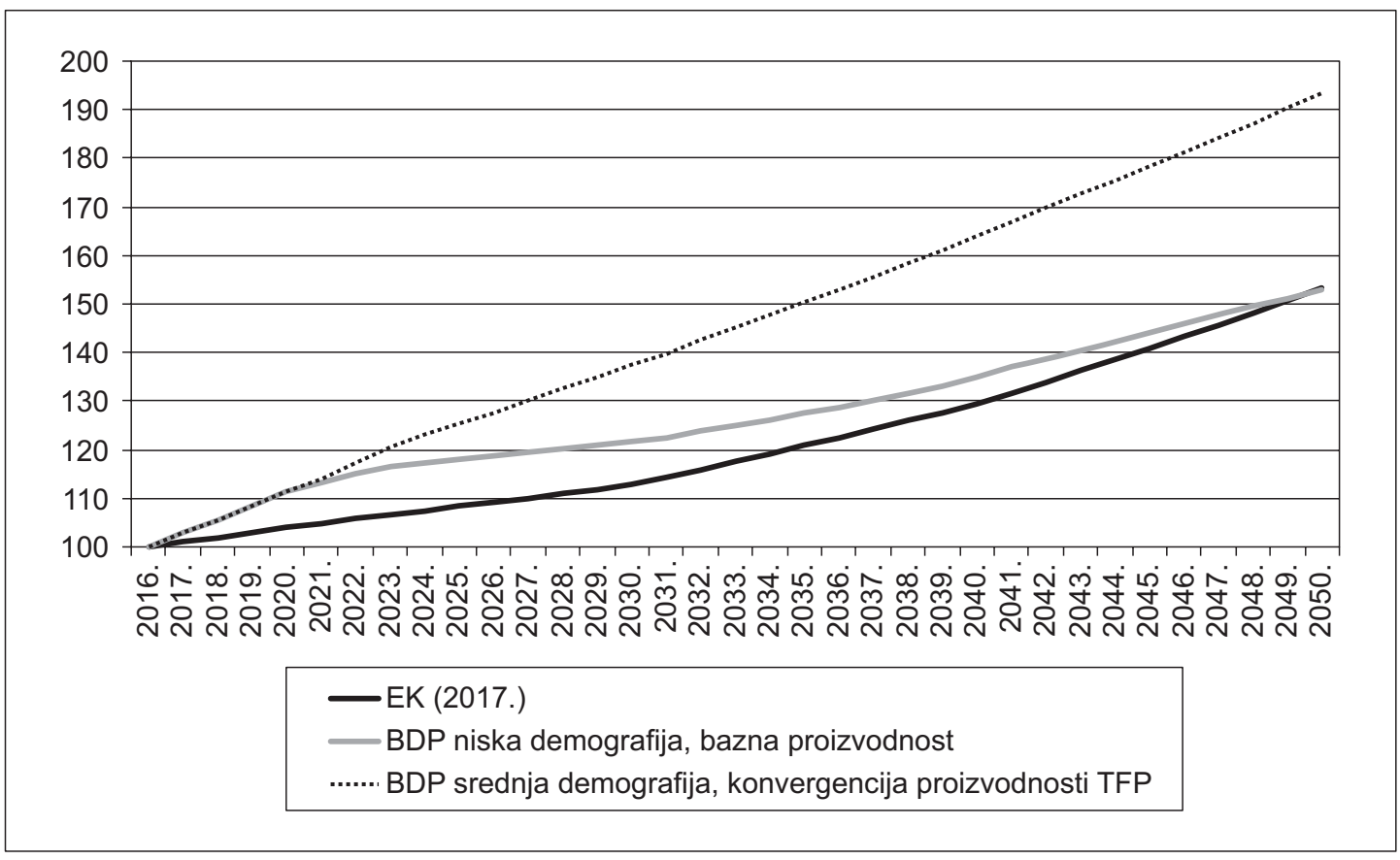

Izvor: Projekcije autora.

Scenarij konvergencije TFP omogućava RH da u određenoj mjeri smanji jaz u razvijenosti prema drugim članicama EU, iako ni ta brzina ne osigurava dostizanje prosjeka EU (scenarij 2). Ipak konvergencija TFP omogućuje hvatanje priključka s novim člancima koje su već prošle razdoblje transformacije gospodarstva i za većinu kojih se očekuje da će do kraja projiciranog razdoblja biti na razini razvijenosti od oko $90 \%$ prosjeka EU28.

Europska komisija u svojim projekcijama očekuje da će čak tri NMS-12 Latvija, Slovačka i Malta do 2050. godine prema pokazatelju BDP po stanovniku biti iznad prosjeka EU. S druge strane, Italija, Portugal i Grčka su primjer starih članica koje, ukoliko se nastave dosadašnji trendovi kretanja proizvodnosti, mogu relativno nazadovati i svrstati se u skupinu slabije razvijenih zemalja EU (Slika 8). Jedino u slučaju konvergencije TFP (scenarij 2) u RH uspjet ćemo do kraja razdoblja (2050.) prestići nove članice EU poput Rumunjske, Mađarske ili Estonije. 
Slika 8.

OČEKIVANE PROMJENE U RELATIVNOJ RAZVIJENOSTI ZEMLJA EU U PROJICIRANOM RAZDOBLJU DO 2050. GODINE, INDEKS BDP PO STANOVNIKU PREMA PARITETU KUPOVNE MOĆI (PPS), EU=100, BEZ KONVERGENCIJE PROIZVODNOSTI U RH I S KONVERGENCIJOM PROIZVODNOSTI

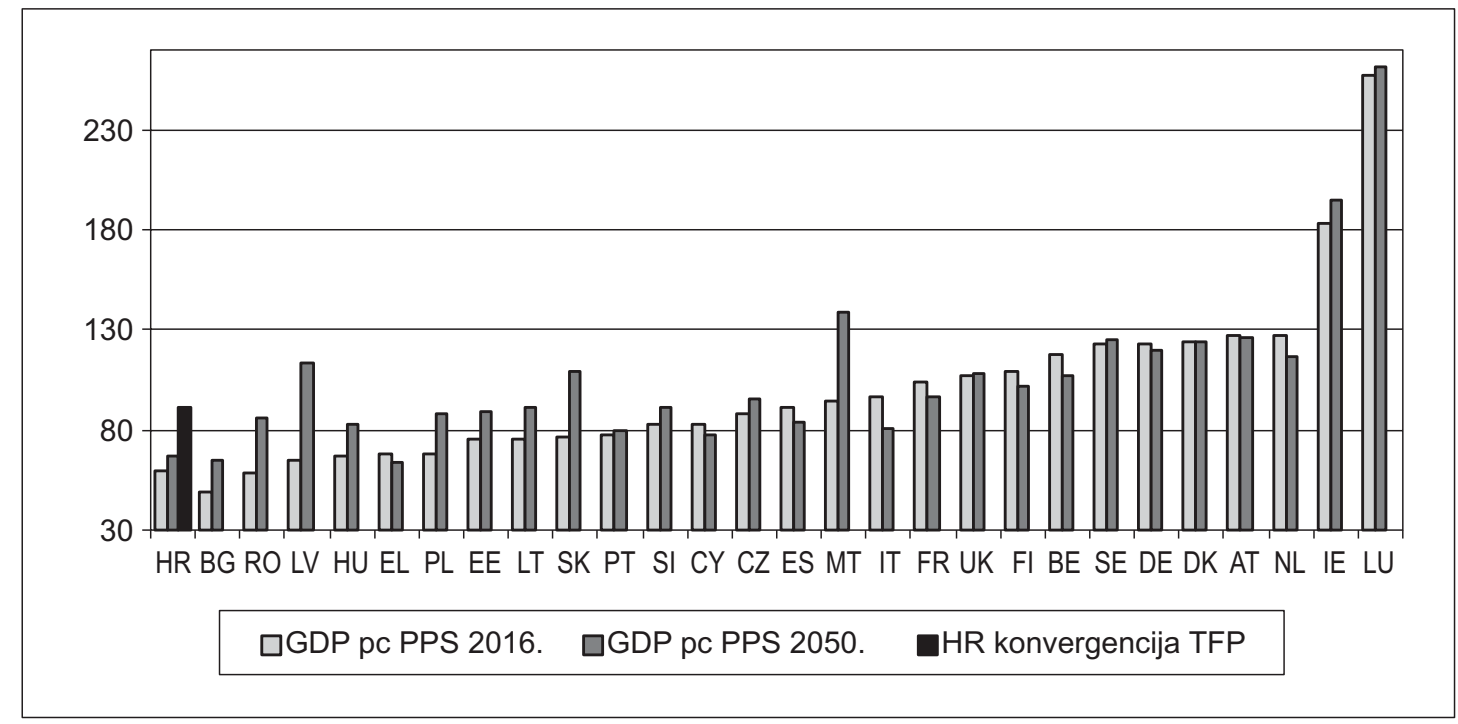

Izvor: Projekcije autora temeljem podataka European Commission (2017).

\section{Zaključak}

Kretanja radne snage projicirana su temeljem dugoročnih demografskih kretanja i očekivanih stopa aktivnosti pojedinih dobno-spolnih skupina u RH. Projekcija proizvodnosti rada određena je pretpostavkama o kretanju osnovnih faktora koji na nju utječu: kapitalne opremljenosti rada i TFP. U projekcijama TFP se koriste spoznaje utvrđene $u$ istraživanjima stručnjaka za izradu dugoročnih europskih projekcija, a središnja pretpostavka europskog modela jest nastavak procesa konvergencije proizvodnosti rada do 2050 godine.

Osim osnovnog scenarija kretanja proizvodnosti za hrvatsko gospodarstvo koji je korišten kao bazni scenarij -1, u europskim projekcijama, uveden je i jedan optimističniji scenarij u kojem rast ukupne proizvodnosti faktora RH konvergira prema brzini rasta novih članica EU, scenarij 2. Osnovni scenarij u europskim 
projekcijama podrazumijeva izostanak konvergencije $\mathrm{RH}$ prema razvijenosti EU uslijed nepovoljnih demografskih kretanja i značajnog zaostajanja rasta proizvodnosti u odnosu na ostale nove članice. Prema takvom scenariju, jaz u razvijenosti RH prema drugim novim članicama EU bi se povećavao i RH bi već do kraja desetljeća došla na posljednje mjesto u EU mjereno BDP-om pc, a zaostatak za razvijenim članicama se ne bi smanjivao. To je scenarij propadanja hrvatskog društva u cjelini. Stoga je prikazan alternativni scenarij 2 koji podrazumijeva konvergenciju u brzini rasta ukupne proizvodnosti faktora.

Napravljene gospodarske projekcije do 2050 godine, kroz scenarij 1 i scenarij 2 pokazuju da će se gospodarski rast Hrvatske kretati između 1,1 posto (bazniscenarij 1) do najviše 1,9 posto (scenarij 2) prosječno godišnje, ovisno o pretpostavkama. Rezultati istraživanja potvrđuju glavnu hipotezu da stopa rasta potencijalnog BDP-a više ovisi o kretanju ukupne faktorske proizvodnosti (TFP), nego o demografskim kretanjima. Naime, razlike između različitih stopa rasta BDP-a značajnije ovise o postizanju konvergencije u proizvodnosti (TFP).

Doprinos rasta proizvodnosti u različitim scenarijima doprinosi rastu BDP-a od 1,0 posto u bazičnom (scenariju 1), do 1,8 posto rasta godišnje u scenariju konvergencije (scenarij 2). Stoga dinamika rasta proizvodnosti ponajviše određuje i dinamiku rasta ukupnog BDP-a Hrvatske do 2050. godine.

S druge strane, demografija predstavlja ograničenje i svakako će imati negativan doprinos rastu u svim scenarijima ovisno o stopi aktivnosti stanovništva. Negativan doprinos faktora rada (demografije) rastu BDP-a oscilira od $-0,4$ do $-0,6$ posto godišnje i ima manji značaj na kretanje BDP-a nego ukupna faktorska proizvodnost (TFP). Time je potvrđena glavna hipoteza istraživanja. Rezultati istraživanja su suglasni s istraživanjima Cooley i Henriksen (2018), koji su utvrdili na primjeru SAD i Japana, da u dugom roku, demografska kretanja mogu objasniti svega jednu šestinu dinamike BDP-a per capita, dok ostatak objašnjava kretanje proizvodnosti. Gonzalez Eiras i Niepelt (2012) također zaključuju na primjeru OECD zemalja da demografska tranzicija i starenje dovode do niže stope rasta BDP-a pc, ali ne mogu objasniti ostatak kretanja dinamike BDP-a.

Scenarij konvergencije proizvodnosti je ključ dugoročnog rasta BDP-a per capita Hrvatske, ali i opstanka društva u cjelini. Naime, premda trenutno u fokusu javnosti, različiti demografski scenariji ne mogu značajnije promijeniti ishod ukupnog rasta BDP-a u razdoblju do 2050. godine, već to isključivo može rast proizvodnosti u slučaju Hrvatske, odnosno strukturne reforme. Do sličnih zaključaka dolaze Favero i Galasso (2015) na primjeru petnaest starih članica EU, uz napomenu da oni mogućnost održavanja visoke stope rasta vide u ubrzanim strukturnim reformama što je sve teže izvedivo uz starenje populacije. Rast TFP proizvodnosti u Hrvatskoj podrazumijeva značajno poboljšanje institucionalnog okružja koje će biti poticajnije za rast konkurentnosti hrvatskog gospodarstva, ali 
i promjenu u ponašanju, odnosno socioekonomskom kapitalu. Sve demografske mjere mogu u najboljem slučaju samo ublažiti ili usporiti dinamiku zaostajanja u odnosu na druge članice EU. Samo rast proizvodnosti može osigurati konvergenciju i rast standarda u razdoblju do 2050. godine. U suprotnom će RH već do kraja desetljeća doći na začelje EU zemalja, i ondje ostati do kraja projiciranog razdoblja - 2050. godine.

\section{Popis literature}

Adamec, V. i Střelec, L. (2012). Study of potential output and output gap in the Czech Republic. Acta Universitatis Agriculturae et Silviculturae Mendelianae Brunensis, LX(2), 9-16. DOI: https://doi.org/10.11118/actaun201260020009

Bokan, N. i Ravnik, R. (2012). Procjena potencijalnog outputa u Republici Hrvatskoj primjenom multivarijantnog filtra. Istraživanja I-38, Hrvatska narodna banka, Zagreb, 1-16.

Buturac, G, Lovrinčević, Ž. i Mikulić, D. (2011). Macroeconomic performance, trade and competitiveness of south-eastern European countries, Ekonomski pregled, 62(9-10), 483-507.

Cooley, T. F. i Henriksen, E. (2018). The demographic deficit. Journal of Monetary Economics (93), 45-62.

Denis, C., Mc Morrow, K. i Roeger, W. (2002). Production function approach to calculating potential growth and output gaps - estimates for the EU Member States and the US. European Economy - Economic Papers 2008 - 2015 176, European Commission.

Epstein, N. i Macchiarelli, C. (2010). Estimating Poland's Potential Output; A Production Function Approach. IMF Working Papers 10/15, International Monetary Fund.

Energetski institut Hrvoje Požar. (2018). Analize i podloge za izradu energetske strategije Republike Hrvatske - Zelena knjiga, Zagreb, dostupno na: https:// www.mzoip.hr/doc/analize_i_podloge_za_izradu_energetske_strategije_republike_hrvatske_-_zelena_knjiga_nacrt.pdf

Europska komisija. (2018). Izvješće za Hrvatsku 2018. s detaljnim preispitivanjem o sprječavanju i ispravljanju makroekonomskih neravnoteža, Bruxelles.

European Commission. (2017). The 2018 Ageing Report: Underlying Assumptions \& Projection Methodologies. European Economy - Institucional paper 065.

Favero, C. A. i Galasso, V. (2015). Demographics and the secular stagnation in Europe. CEPR Discussion Paper 10887. 
Ganev, K. (2015). Small Model for Output Gap and Potential Growth Estimation: An Application to Bulgaria. Bulgarian Economic Papers BEP 04-2015, Center for Economic Theories and Policies.

Garcia-Saltos, R., Teodoru, I.R. i Zhang, F. (2016). Potential Output Growth Estimates for Central America and the Dominican Republic. IMF Working Papers WP/16/250, International Monetary Fund.

Gonzalez Eiras, M. i Niepelt, D. (2012). Ageing, government budgets, retirement, and growth. EuropeanEconomic Review, 56(1), 97-115.

Hájková, D. i Hurník, J. (2007). Cobb-Douglas Production Function: The Case of a Converging Economy. Czech Journal of Economics and Finance, 57(9-10), 465-476.

Havik, K., Mc Morrow, K., Orlandi, F., Planas, C., Raciborski, R., Roeger, W., Rossi, A., Thum-Thysen, A. i Vandermeulen, V. (2014). The Production Function Methodology for Calculating Potential Growth Rates \& Output Gaps. European Economy - Economic Papers 2008 - 2015 535, European Commission.

Jovičić, G. (2017). Procjena potencijalnog rasta i jaza BDP-a u Hrvatskoj. Pregledi, $P-38$, Hrvatska narodna banka, Zagreb, 1-10.

Larch, M. i Turrini, A. (2009). The cyclicylly-adjusted budget balance in EU fiscal policy making: A love at first sight turned into a mature relationship. Economic Papers 374, EC.

Leimbach, M., Kriegler, E., Roming, N. i Schwanitz, J. (2017). Future growth patterns of world regions - A GDP scenario approach. Global Environmental Change, 42, 215-225. DOI: https://doi.org/10.1016/j.gloenvcha.2015.02.005

Măntescu, D. i Lazăr, D.T. (2014). Estimation of potential GDP and output gap - comparative perspective. Amfiteatru Economic Journal, 16(37), 951-964.

Onalan, O. i Basegmez, H. (2018). Estimation of economic growth using grey Cobb-Douglas production function: an application for US economy. Business, Economics and Finance (JBEF), 7(2), 178-190. DOI: http://doi.org/10.17261/ Pressacademia.2018.840

Solow R. (1956). A contribution to the theory of economic growth. Quarterly Journal of Economics, 70(1), 65-94. DOI: https://doi.org/10.2307/1884513 


\section{PRILOG:}

P1. Demografske projekcije po dobno-spolnim skupinama, niski demografski scenarij

\begin{tabular}{|l|r|r|r|r|r|r|r|c|}
\hline & 2016. & 2021. & 2031. & 2041. & 2051. & $\begin{array}{c}\text { Razlika } \\
\text { 2051.-2016. }\end{array}$ & $\begin{array}{c}\text { Indeks } \\
\text { 2051./2016. }\end{array}$ & $\begin{array}{c}\text { Prosječna } \\
\text { godišnja } \\
\text { stopa }\end{array}$ \\
\hline Muškarci & & & & & & & & \\
\hline $15-24$ & 238 & 215 & 198 & 170 & 149 & -90 & 62.4 & -1.1 \\
\hline $25-49$ & 671 & 631 & 564 & 517 & 462 & -210 & 68.8 & -1.1 \\
\hline $50-64$ & 436 & 409 & 375 & 355 & 322 & -114 & 73.9 & -0.9 \\
\hline $65+$ & 323 & 360 & 412 & 419 & 426 & 102 & 131.7 & 0.8 \\
\hline Ukupno (15-64) & 1,345 & 1,255 & 1,137 & 1042 & 933 & -413 & 69.3 & -1.0 \\
\hline Žene & & & & & & 0 & & \\
\hline $15-24$ & 228 & 205 & 188 & 162 & 142 & -86 & 62.1 & -1.4 \\
\hline $25-49$ & 661 & 620 & 552 & 499 & 442 & -219 & 66.9 & -1.1 \\
\hline $50-64$ & 459 & 433 & 386 & 361 & 324 & -135 & 70.6 & -1.0 \\
\hline $65+$ & 488 & 515 & 560 & 552 & 537 & 49 & 110.0 & 0.3 \\
\hline Ukupno (15-64) & 1,348 & 1,259 & 1,126 & 1022 & 908 & -440 & 67.3 & -1.1 \\
\hline & & & & & & & & \\
\hline $15-24$ & 466 & 421 & 386 & 332 & 290 & -176 & 62.3 & -1.3 \\
\hline $25-49$ & 1,332 & 1,251 & 1,115 & 1016 & 904 & -428 & 67.8 & -1.1 \\
\hline $50-64$ & 895 & 842 & 761 & 717 & 647 & -249 & 72.2 & -0.9 \\
\hline $65+$ & 811 & 875 & 972 & 970 & 962 & 151 & 118.6 & 0.5 \\
\hline Ukupno (15-64) & 2,694 & 2,513 & 2,262 & 2064 & 1841 & -853 & 68.3 & -1.1 \\
\hline Ukupno (15+) & 3,505 & 3,389 & 3,234 & 3034 & 2803 & -702 & 80.0 & -0.6 \\
\hline
\end{tabular}

Izvor: Energetski institut Hrvoje Požar (2018). 
P2. Demografske projekcije po dobno-spolnim skupinama, srednji demografski scenarij

\begin{tabular}{|l|r|r|r|r|r|r|r|c|}
\hline & 2016. & 2021. & 2031. & 2041. & 2051. & $\begin{array}{c}\text { Razlika } \\
\text { 2051.-2016. }\end{array}$ & $\begin{array}{c}\text { Indeks } \\
\text { 2051./2016. }\end{array}$ & $\begin{array}{c}\text { Prosječna } \\
\text { godišnja } \\
\text { stopa }\end{array}$ \\
\hline Muškarci & & & & & & & & \\
\hline $15-24$ & 238 & 215 & 198 & 175 & 160 & -78 & 67.4 & -0.8 \\
\hline $25-49$ & 671 & 631 & 564 & 517 & 467 & -204 & 69.6 & -1.0 \\
\hline $50-64$ & 436 & 409 & 375 & 355 & 322 & -114 & 73.9 & -0.9 \\
\hline $65+$ & 323 & 360 & 412 & 419 & 426 & 103 & 131.7 & 0.8 \\
\hline Ukupno (15-64) & 1,345 & 1,255 & 1,137 & 1047 & 950 & -396 & 70.6 & -1.0 \\
\hline Žene & & & & & & 0 & & \\
\hline $15-24$ & 228 & 205 & 188 & 167 & 153 & -75 & 67.1 & -1.1 \\
\hline $25-49$ & 661 & 620 & 552 & 499 & 447 & -214 & 67.6 & -1.1 \\
\hline $50-64$ & 459 & 433 & 386 & 361 & 324 & -135 & 70.6 & -1.0 \\
\hline $65+$ & 488 & 515 & 560 & 552 & 537 & 49 & 110.0 & 0.3 \\
\hline Ukupno (15-64) & 1,348 & 1,259 & 1,126 & 1027 & 924 & -424 & 68.6 & -1.1 \\
\hline & & & & & & & & \\
\hline $15-24$ & 466 & 421 & 386 & 341 & 313 & -153 & 67.2 & -1.1 \\
\hline $25-49$ & 1,332 & 1,251 & 1,115 & 1016 & 914 & -418 & 68.6 & -1.1 \\
\hline $50-64$ & 895 & 842 & 761 & 717 & 647 & -249 & 72.2 & -0.9 \\
\hline $65+$ & 811 & 875 & 972 & 970 & 962 & 151 & 118.6 & 0.5 \\
\hline Ukupno (15-64) & 2,694 & 2,513 & 2,263 & 2074 & 1874 & -820 & 69.6 & -1.0 \\
\hline Ukupno (15+) & 3,505 & 3,389 & 3,234 & 3045 & 2836 & -668 & 80.9 & -0.6 \\
\hline
\end{tabular}

Izvor: Energetski institut Hrvoje Požar (2018). 
P3. Demografske projekcije po dobno-spolnim skupinama, visoki demografski scenarij

\begin{tabular}{|l|r|r|r|r|r|r|r|c|}
\hline & 2016. & 2021. & 2031. & 2041. & 2051. & $\begin{array}{c}\text { Razlika } \\
\text { 2051.-2016. }\end{array}$ & $\begin{array}{c}\text { Indeks } \\
\text { 2051./2016. }\end{array}$ & $\begin{array}{c}\text { Prosječna } \\
\text { godišnja } \\
\text { stopa }\end{array}$ \\
\hline Muškarci & & & & & & & & \\
\hline $15-24$ & 238 & 215 & 199 & 189 & 171 & -67 & 72.0 & -0.7 \\
\hline $25-49$ & 671 & 631 & 573 & 524 & 483 & -188 & 72.0 & -0.9 \\
\hline $50-64$ & 436 & 409 & 378 & 360 & 329 & -107 & 75.4 & -0.8 \\
\hline $65+$ & 323 & 360 & 413 & 420 & 429 & 106 & 132.7 & 0.8 \\
\hline Ukupno (15-64) & 1,345 & 1,255 & 1,150 & 1073 & 983 & -362 & 73.1 & -0.9 \\
\hline Žene & & & & & & 0 & & \\
\hline $15-24$ & 228 & 205 & 189 & 180 & 163 & -64 & 71.7 & -0.9 \\
\hline $25-49$ & 661 & 620 & 560 & 505 & 462 & -199 & 69.9 & -1.0 \\
\hline $50-64$ & 459 & 433 & 388 & 366 & 330 & -129 & 71.8 & -0.9 \\
\hline $65+$ & 488 & 515 & 560 & 554 & 540 & 52 & 110.7 & 0.3 \\
\hline Ukupno (15-64) & 1,348 & 1,259 & 1,137 & 1050 & 956 & -393 & 70.9 & -1.0 \\
\hline & & & & & & & & \\
\hline $15-24$ & 466 & 421 & 389 & 369 & 335 & -131 & 71.9 & -0.9 \\
\hline $25-49$ & 1,332 & 1,251 & 1,133 & 1029 & 946 & -387 & 71.0 & -1.0 \\
\hline $50-64$ & 895 & 842 & 766 & 726 & 659 & -237 & 73.6 & -0.9 \\
\hline $65+$ & 811 & 875 & 973 & 974 & 969 & 158 & 119.5 & 0.5 \\
\hline Ukupno (15-64) & 2,694 & 2,513 & 2,287 & 2123 & 1939 & -754 & 72.0 & -0.9 \\
\hline Ukupno (15+) & 3,505 & 3,389 & 3,260 & 3097 & 2909 & -596 & 83.0 & -0.5 \\
\hline
\end{tabular}

Izvor: Energetski institut Hrvoje Požar (2018). 


\title{
DOES LONGTERM GROWTH OF CROATIAN ECONOMY DEPEND ON DEMOGRAPHY OR PRODUCTIVITY AFTER ALL?
}

\begin{abstract}
Summary
The aim of this paper is to provide long-term projections of economic growth in the Republic of Croatia for the period up to 2050. Long-term projections of the economic growth are useful tool for identification of potential growth limitations related to different socioeconomic issues: demography, fiscal sustainability, environmental protection and many other aspects. The projections are based on Cobb-Douglas's type of production function in order to be comparable to European Commission long-term projections for all member states. Expected long-term economic developments are based on demographic projections, as well as projections of capital deepening and total factor productivity growth. Long-term projections are faced to many uncertainties, especially path of total factor productivity path in the long run. Research results point to the increase of investment efficiency and total factor productivity growth as the most important drivers for long-term growth. In addition, labor market participation rate seems to be of utmost importance. This could, at least to some extent, mitigate negative demographic trends and further working-age population shrinking.

Long-term projections are usually faced to a high level of uncertainty. Many variables are exposed to future changes in alternative scenarios. The results and conclusions presented in this paper fill the gap in domestic literature on the long term potential growth in the Republic of Croatia. The alternative scenarios of growth could serve as a basis for a number of strategic documents dealing with energy, regional policy, industry, demographic, health, and environmental protection issues. The research results suggest that the average annual economic growth rate in Croatia up to 2050 in Croatia would be in range of 1.1 percent (base scenario) up to 1.9 percent, depending on the growth rate of total factor productivity. Potential GDP growth rate is more dependent on factor productivity rather than demography.
\end{abstract}

Key words: long-term economic growth, convergence, projections, total factor productivity. 